\title{
Professionalism in higher education: important not only for lawyers
}

\author{
Egle Dagilyte \& Peter Coe
}

\section{Introduction}

The legal services landscape is changing. As the sector is becoming increasingly geared towards consumerism ${ }^{1}$ and economic efficiency, it has borne multiple variants of the "lawyer", many of whom are not solicitors or barristers and have not undergone the typical professional preparation that includes vocational ${ }^{2}$ and on-the-job training. ${ }^{3}$ In this way, the changing landscape of legal services provides multiple routes to work within the legal industry. The linear legal education model (academic stage $\rightarrow$ LPC/BPTC stage $\rightarrow$ on-the-job training) seems to follow the trend of diversification, increasing the variety of pathways into legal practice, which allows for those without a law degree to give legal advice.

The challenge for legal educators is to adapt to this transition in a way that continues to deliver effective legal education, by producing employment-ready graduates and postgraduates. Thus, at the very heart of being employment-ready, in any industry, is the notion of professionalism. The concept rose to prominence in the second half of the twentieth century, ${ }^{4}$ and the effort to maintain "the aura of professionalism" ${ }^{5}$ is visible in the key reports that predate the LETR. ${ }^{6}$ In 1997 the ACLEC Report acknowledged that the increasing internationalisation and commercialisation of higher education magnified the divergence between academic and professional legal education. ${ }^{7}$ Hence the LETR Committee proposed to integrate academic and professional stages of legal training, and described what both stages should aim for: intellectual integrity and independence of mind, core knowledge, contextual knowledge, legal values, and professional skills. ${ }^{8}$ The LETR's call to "strengthen requirements for education and training in legal ethics, values and professionalism" ${ }^{9}$ has once again placed the notion of professionalism firmly in the spotlight. For these reasons, it is imperative that we determine not only what is meant by professionalism, in the context of the changing landscape of legal services, but also how we can inculcate it in our teaching and work ethos and, consequentially, how we can develop it within our students, in order to provide some common standard of professional values and attitudes for future lawyers in the larger framework of "graduateness".

To reflect the growing importance of professionalism in legal education, the body of this article is divided into three sections. Sections 2 and 3 consider definitions of professionalism and provide an applicable articulation of the notion within the context of the changing landscape of legal services. Section 4 considers the challenges for legal educators in applying and inculcating an accepted articulation of professionalism. Taking into account the LETR recommendations, the article concludes with some practical proposals as to how professional skills, attitudes and values could be developed in higher education degree programmes.

\section{Defining professionalism}

The term "professionalism" is not easy to define. Hamilton observes ${ }^{10}$ that "legal scholars have so far been unable to construct and agree on a widely-accepted, clear and succinct definition of 'professionalism'" ${ }^{11}$ He identifies three strands of literature: the first strand tries to avoid defining professionalism at all, assuming that it exists as a given within the legal profession and instead concentrates on how professionalism is in decline, identifying problems in the profession; the second strand seems to focus on "one or more characteristics of professionalism that are the 'core' of professionalism"12 (e.g. core values, professional standards, individual morality, respect for community); finally, the last strand of scholarship rejects professionalism as one-way thinking about how the legal profession should function, as there may be no "one universal way to be a legal professional". ${ }^{13}$

How is professionalism defined in the LETR? The Report does not provide a definition for this term and instead describes professionalism in different contexts such as competencies, ${ }^{14}$ expected core learning outcomes, ${ }^{15}$ the legal profession's values, ${ }^{16}$ personality attributes/habits of mind ${ }^{17}$ or ethical awareness. ${ }^{18}$ It appears that the LETR reflects 
Hamilton's second strand of literature, as it focuses on certain characteristics of professionalism. The Report notes that professionalism has a close relationship with competence, acknowledging that the term "competence", too, is not used consistently across the legal sector, and that to some extent it may be "determined by context, so that what is described as a 'learning outcome' in the classroom may be identical to an achievement described by an employer or professional body as a 'competence' in the workplace" ${ }^{19} \mathrm{It}$ is not surprising that the recent focus on employability in higher education (HE) aims to develop the competencies valued by employers, through introducing assessments testing these employment-friendly skills incorporated in learning outcomes. Thus, professional competence denotes not only subject-specific knowledge, but also soft skills and meta-competencies. ${ }^{20}$ The latter include "the ability to manage ambiguous problems, tolerate uncertainty, and make decisions with limited information"; ${ }^{21}$ managing uncertainty; monitoring and evaluating one's own cognitive processes; ${ }^{22}$ personal, creative and emotional intelligence. ${ }^{23}$

Given such varied terminology and the close connotation between professionalism, competence, and employability, how could we concisely define the lucid concept of professionalism? In light of the literature on established professions - such as the clergy, law, engineering, nursing and medicine - Colby and Sullivan provide the following definition of professionalism (emphasis added):

Professions involve (at least) a commitment to serve the interests of clients and the welfare of society; bodies of specialized knowledge and skill; and procedures through which the professional community provides oversight of entry into the profession and quality in both practice and professional training. ${ }^{24}$

From the above we can identify a four-dimensional framework that defines professionalism: (1) intellectual training to learn the academic knowledge; (2) a skill-based practice; (3) certain values: ethical standards, social roles and responsibilities of the profession grounded in its fundamental purposes; and (4) the existence of professional regulatory bodies that concern themselves with how professionals are trained and perform their work. ${ }^{25}$

The LETR seems to draw inspiration ${ }^{26}$ on how professionalism is built from Epstein and Hundert's multidimensional model on professional competencies. It looks, first, at the discipline-specific knowledge (i.e. knowledge of law); secondly, at professional skills (lawyering skills, as well as other general employability skills); ${ }^{27}$ thirdly, at a set of professional values that underpin the first two attributes and that continue to develop through one's career and life. ${ }^{28}$ This concept of professionalism is much wider than Colby and Sullivan's definition, and there are some similarities to how "graduateness" is defined in scholarly literature. ${ }^{29}$ The latter can be viewed as "the common qualities that graduates should have", ${ }^{30}$ pointing to a much wider set than what is known as "employability skills", ${ }^{31}$ despite the fact that graduateness today has come to be even more closely linked with employability. ${ }^{32}$

Based on the definitions of professionalism articulated above, it appears that the notion can be seen in two distinct ways. First, as professionalism in the narrow sense, this implies regulation of law practitioners by the professional bodies. This type of professionalism reflects the traditional understanding of professions, where becoming a lawyer requires supervised - linear - legal education, as well as observance of professional standards after qualification to practise as a solicitor or a barrister. In terms of education, the focus when preparing such regulated legal professionals is very much on developing their legal knowledge, lawyering skills and values that are in line with the values of the regulatory bodies.

In contrast to the above definition, professionalism can also be understood in the wide sense, which does not require regulation by the professional bodies and focuses instead on skills and values that any professional should possess or have. Entry into legal services today can be gained through a variety of non-linear pathways, in terms of both education and on-the-job training. It is likely that, in light of the current changes to legal services, many graduates will become lawyers, not via the regular linear route that solicitors and barristers typically follow, but also through on-the-job training. Arguably, by the time a student finishes a law degree or Graduate Diploma in Law, much of the knowledge gained is either out of date or, for example, in the case of a graduate obtaining a training contract in a corporate firm, not applicable. Given the changing nature of legal services, it is quite common that the 
knowledge required "to do the job" is acquired through work experience, by practising as a lawyer (e.g. as a CILEx member). Thus, instead of strict regulation, the focus of higher education should be on developing the common standard of professional skills, values and attitudes that are universal: accepted not only by the legal profession, but also by others (e.g. accountancy, architecture, medicine, etc.). The transferrable professional skills, values and attitudes that will enable any graduate to apply knowledge successfully need to be in place from the moment the graduate enters the job market. In the words of the LETR: ${ }^{33}$

There is still a tendency within some, particularly more task-based, [professional] competence frameworks to focus on a relatively narrow range of cognitive competencies, leaving the development of soft skills ... implicit. This may mean that insufficient attention is given to those skills and meta-competencies in the education and training process.

To summarise, the wider notion of professionalism places more stress on skills, values and attitudes that can be developed via higher education and on-the-job training, instead of focusing on knowledge acquisition and regulation by professional bodies. Thus, this article considers and applies professionalism in the wider sense: as skills, personal attitudes and values that guide one's behaviour when providing legal advice. The reasons for the application of the wider articulation are amplified in the context of a diversifying legal services market, examples of which are set out in the section below.

\section{The changing landscape of legal services and higher education: challenges for professionalism}

According to Colby and Sullivan's narrow definition outlined above, ${ }^{34}$ professionalism includes being a member of, and regulated by, a professional body. However, as we argued earlier, the emergence of diverse routes into working within legal services has meant that a person can now practise law without having taken the more traditional linear route to qualification. The potential for greater diversification of legal services (especially in the commercial sector) is possible because of the type of work that lawyers undertake. Legal services are split between reserved activities (e.g. litigation or commercial conveyancing) and unreserved activities (e.g. transactional work, will writing or employment advice). Typically, qualified and regulated solicitors will undertake both types of activity, whereas nonqualified lawyers, who have not undergone professional vocational training (LPC/BPTC), can undertake only unreserved activities. Although unreserved work was performed by non-qualified lawyers even before the introduction of alternative business structures (ABSs), the advent of the ABS regime has been the catalyst for greater numbers of traditionally non-legal companies entering the legal services market. Consequently, there are now diverse routes into working within legal services. The ABS illustrates this point, as set out below.

The 2004 Clementi Review ${ }^{35}$ recommended the introduction of ABSs. These were to be implemented via two distinct routes: ${ }^{36}$ the legal disciplinary practice (LDP) or the multidisciplinary practice (MDP). ${ }^{37}$ The former permits lawyers from different professional bodies - e.g. barristers and solicitors - to work together to provide legal services; ${ }^{38}$ while the latter enables lawyers, as well as other professionals - e.g. accountants, chartered surveyors and auditors - to work in unison to provide legal and other services. ${ }^{39}$ Additionally, the ABS regime allows for external ownership of these structures. Driven by the financial benefits of these new business opportunities, a number of well-known nonlegal businesses have expanded into the sector, ${ }^{40}$ including, for example, The Co-operative Legal Services. ${ }^{41}$

If we are to apply Colby and Sullivan's definition of professionalism to ABSs, at first sight it would seem nonproblematic, as the employees of these new structures are governed by professional bodies. Thus, if a business or firm wishes to become an ABS, it must first be granted a licence by the Solicitors Regulation Authority (SRA); ${ }^{42}$ there are currently 196 ABSs licensed in this way. ${ }^{43}$ Being a licensed ABS enables the company or firm to undertake both reserved and unreserved work. However, the reality today is quite different, as there are thousands of other organisations that provide legal services that are not licensed in this way. For example, AA Legal Services ${ }^{44}$ and Direct Line (DLG Legal Services) ${ }^{45}$ have recently entered the legal services market, but neither company features on the SRA register of licensed ABSs. Consequently, in theory at least, these organisations, and many others, will be undertaking 
unreserved work and, as they are not licensed, their practice will be beyond the regulatory remit of the SRA. As a result, within these organisations there may not be any "typically" qualified and regulated lawyers overseeing the advice being given. This "reality check" on how legal service providers function gives rise to two conflicting arguments regarding the wider definition of professionalism, as adopted by this article: (1) on the one hand regulation by a professional body will at least go some way to ensuring a common standard of professional behaviour by providing a framework within which individuals can operate; (2) on the other hand professionalism, and being professional, should not depend upon membership of, and regulation by, a professional body, especially as such a body cannot possibly reach every corner of the current legal marketplace. Therefore, Colby and Sullivan's narrow definition of professionalism is not suitable for the modern, diverse legal market, where there are various pathways into working within legal services. This is illustrated by AA Legal Services and DLG Legal Services which will employ people to provide legal advice who have not entered the legal services market via the traditional linear pathway. These employees may not be subject to regulation in the same way as a barrister or solicitor, but will still need to be subject to, and maintain, a common professional standard. Consequently, the transforming landscape of legal services requires higher education to change in order to address the issues with professionalism that have been identified in this article. There are at least three challenges for higher education in relation to this that are discussed below: (1) ensuring the public purpose of legal services; (2) designing professional institutional set-up; (3) providing high-quality pedagogy training. These will be dealt with in turn, below.

\section{The challenges for educators}

In applying the wider definition of professionalism, what are the challenges facing legal educators? In relation to the LETR, in order to ensure professionalism survives in the changed environment in which the legal profession operates today, ${ }^{46}$ three aspects of legal training need to be addressed: (1) the knowledge; (2) the skills; and (3) the attitudes and values that professional lawyers should possess. We focus on the latter two aspects that are applicable not only to legal services, but also to wider industry, especially as the Confederation of British Industry found that up to 2017 the major areas of anticipated job expansion were for managers, professionals and associate professionals. ${ }^{47}$ For example, the call for professionalism was the central tenet in Lord Stevens' recent report entitled "Policing for a Better Britain" on the need to restructure police as a profession that serves the public. ${ }^{48}$ To illustrate the crossdisciplinary rise of the need for professional values and attitudes, the LETR Report draws inspiration on how professionalism is ingrained in the healthcare and financial sectors "where the risks from incompetent practice are particularly high". ${ }^{49}$ The Report bases its findings on Epstein and Hundert's multidimensional model of professional competence in medicine ${ }^{50}$ and compares the drive for "professional as opposed to technical education" ${ }^{51}$ in accountancy, in order to reflect on the changes that are taking place in the legal sector today. It follows that in the future the demand for professional workers will be high across a range of industries, including policing, medicine, accountancy, and law. As professionalism standards are converging, law academics must be alert to developments in other fields, in order to ensure that law graduates are equipped with the knowledge and skills to enable them not only to go on to the LPC or BPTC, but also to enter, and operate effectively within, other industries, while being able to reflect on their practice in light of ethical values of what it means to be and act as a professional.

The above trends are strengthened by statistical data on law graduates, which shows that many choose careers outside legal practice. According to the Higher Education Statistics Agency, law graduates who are in employment six months post-graduation end up in jobs related not only directly to law (15\%), but also to business or financial services (10\%); while others go on to further study $(30 \%)^{52}$ before entering the job market. With, for example, the number of training contracts registered in the 12-month period to July 2012 dropping to 4869 - a decline of $10.5 \%$ from the previous year ${ }^{53}$ - many law graduates do not enter the legal profession after acquiring a law degree, even though at the beginning of their studies this may be the preferred and popular destination. ${ }^{54}$ As the legal market becomes increasingly competitive and more difficult for graduates to access via the LPC or BPTC, many graduates choose diverse employment options or postgraduate education. For the above reasons, a task for law educators is not just ensuring that university graduates know the law (which changes quickly, and thus may not even be 
applicable in other industries), but ensuring that they also develop an understanding of professional skills and values; these will inform not only what they do in their careers, but how they do it.

The converging standards of professionalism have also been articulated by a number of academic commentators, who have expressed a need for a common standard of professionalism to be developed across a variety of degree disciplines. As Bradney observes, a "pure" liberal law degree is no longer fit for current economic and societal needs. ${ }^{55}$ Thus, it is argued that higher education needs to be combined with skills and values training to prepare graduates that are fit both for non-legal employment, as well as for professional legal training. Hepple sees the division of academic and professional legal training as a negative dichotomy, or "the false antithesis between 'liberal' and 'professional' legal education", ${ }^{56}$ which was the result of the Ormrod Report. In reaction to Ormrod, Arthurs noted the need to do away with the "oft-repeated experience of students who at the academic stage were engaged in abstract intellectual debate, and were then asked to engage at the professional stage in 'mundane, quasi-clerical work' which would lead to a 'severe loss in morale and idealism'" ${ }^{57}$ As Hepple observes, the ACLEC Report favoured "integrated education and training, in which liberal values and transferable professional skills [were] learnt throughout the educational process by in-depth study of Law" (emphasis added)..$^{58}$ This was the call for the traditional linear model of academic and vocational stages (that result in the qualification of barrister or solicitor) to be replaced "by the notion of life-long personal development in the law as a liberal and humane profession" (emphasis added). ${ }^{59}$ For these reasons it is a positive recommendation by the LETR to address skills and values at university level, ${ }^{60}$ in order to create a seamless progression towards professional training for those law graduates who wish to do so. ${ }^{61}$

Considering the above, what are the recommendations by the LETR for improving the development of professionalism in higher education? One recommendation is to improve professional skills training, by stressing skills such as legal research, written and oral communication, ${ }^{62}$ management, equality and diversity, ${ }^{63}$ commercial awareness, advocacy and leadership (supervision of trainees and others). ${ }^{64} \mathrm{~A}$ similar need for "non-technical" skills is also demanded by other professions, such as accountancy, where there have been numerous calls to develop teamwork and communication skills, ${ }^{65}$ commercial and technological awareness, ${ }^{66}$ and the capacity for lifelong learning. ${ }^{67}$ According to the LETR, these skills are to be assessed by including appropriate learning outcomes and "a distinct assessment of legal research, writing and critical thinking skills at level five or above" ${ }^{68}$ While doing so, legal educational providers should "retain discretion in setting the context and parameters of the task, provided that it is sufficiently substantial to give students a reasonable but challenging opportunity to demonstrate their competence" ${ }^{69}$ Thus, as with professional knowledge, ${ }^{70}$ the LETR leaves sufficient flexibility for providers of legal services education and training (LSET) to design learning outcomes and assessments, as well as the restructuring - if required - of their law programmes ${ }^{71}$ to implement these recommendations. A wealth of legal skills modules is already available at many universities in the United Kingdom, some of which also offer sandwich degrees that include work experience opportunities. The LETR sees practical work experience, integrated into law degrees, as a positive way to develop the professional skills outlined above. The Review is cautious about the financial and other implications these kinds of degree structures may have, ${ }^{72}$ and for these reasons leaves LSET providers free to choose whether to adopt such degree structures for their programmes.

The third aspect of professionalism - professional values and attitudes - was also stressed by the LETR. ${ }^{73}$ The call for including professional ethics in academic training was already visible in Justice's reaction ${ }^{74}$ to the Ormrod Report, which "wanted to see greater emphasis on 'practical training', including 'some training in office management' for both branches of the profession, including 'professional ethics'" ${ }^{75}$ ACLEC, too, noted that "the ethical challenge goes beyond client-based services, to 'wider social and political obligations' such as protection of the rights of minorities". ${ }^{76}$ Reflecting these calls, the LETR identifies a much greater need to focus on "the centrality of professional ethics and legal values" ${ }^{177}$ and calls for "regulators ... to consider developing a broad approach to this subject rather than a limited focus on conduct rules or principles". ${ }^{78}$ As guidance for professional values training, the LETR looked at the Scottish vocational Professional Education and Training (PEAT). Stage one of PEAT ${ }^{79}$ involves training on professional values such as the interests of justice and society; effective and competent legal services on 
behalf of the client; continuing professional education and development; diversity and public service; trust, respect and personal integrity. ${ }^{80}$ The LETR proposes that learning outcomes in the academic stage include "reference ... to an understanding of the relationship between morality and law, the values underpinning the legal system, and the role of lawyers in relation to those values" ${ }^{81}$ The LETR seems to leave a lot of flexibility for universities to include professional values training into law programmes, in particular stating that "there is no consensus to include professional ethics as a discrete Foundation subject". ${ }^{82}$ However, at the same time it suggests that skills and values training must be given greater importance at this stage than they are being given at the moment. ${ }^{83}$

In light of the wider definition of professionalism advanced in this article, and in the context of the increasing pathways into working within legal services, in order to achieve a common professional standard, it can be argued that the development and inculcation of professional skills, attitudes and values should feature in many undergraduate degrees. How can academics ensure that professionalism, as defined in this article, is addressed in higher education?

One way of answering this question is to allow for reasonable academic discretion when constructing degrees, as long as that discretion is exercised with the awareness of the pedagogical tools and methods that help future professionals to develop not only their knowledge, but also their professional skills, attitudes and values. If a law degree is considered in this context, it becomes unavoidable to incorporate training of skills that are essential for legal professionals.

Reflecting on the skills gap, there is a need to change the strategies and types of assessment in law modules. This was already identified in the Training Framework Review (TFR), "which focused not on learning and teaching methods but on assessment". ${ }^{84}$ The call for improvement of assessment and feedback is clearly visible from the National Student Survey (NSS), which shows that this is the criterion which scores lowest across the whole higher education sector. ${ }^{85}$ For this reason, it is encouraging to see that action is being taken to find ways to improve assessment by the Higher Education Academy. ${ }^{86}$ Thus, improving NSS scores on assessment is an ongoing task for all academics, whether involved in research or teaching; and this task should be undertaken with the aim to improve professionalism.

The LETR recommends enhancing assessment in two ways: first, "through a more robust system of learning outcomes and standards"; ${ }^{87}$ secondly, through "increased standardisation of assessment", ${ }^{88}$ where "education and training providers ... have appropriate methods in place for setting standards in assessment to ensure that students ... have achieved the outcomes prescribed" ${ }^{89}$ In relation to the first, the LETR recommends setting threshold levels of competence "across at least the range of reserved activities and common core skills" at level six as a minimum, ${ }^{90}$ with the long-term aim to develop "a common framework of learning outcomes and standards for the legal services sector as a whole" ${ }^{91}$ In relation to the second way of reforming assessment, it is well-accepted practice in higher education that the knowledge of law is assessed by written exams and coursework. But are these the most suitable assessment methods that develop professional skills, such as the ability to communicate effectively, or the ability to gather and integrate information from various legal sources? An argument can be made that:

the traditional exam is not the best way of assessing these skills because it is limited both by time and by the resources students are able to consult [and] ... in a traditional exam it is difficult to assess if professional skills have been acquired in depth. ${ }^{92}$

Drawing on medical education, the LETR seems to favour new assessment modules being introduced into legal studies: problem-based and case-based learning; ${ }^{93}$ simulation; ${ }^{94}$ independent learning; small group work; ${ }^{95}$ skills sessions; legal-environment-based teaching ${ }^{96}$ computer-based learning; self-reflection; learning portfolios; self and peer assessment. ${ }^{97}$ These assessment techniques, most of which are outcomes-based, are more effective at delivering students who are not only legal training-ready, ${ }^{98}$ but also employer-ready. Finally, to enable the students to choose a career, the LETR suggests that LSET should provide "higher quality and more accessible information on the range of legal careers and the realities of the legal services job market". ${ }^{99}$ 
Looking at professional values and ethics, a number of observations could be made. First, the public purpose of the legal profession must be stressed during all stages of education and should underpin all activities across the legal sector. By delivering legal services, which is a public good, lawyers discharge public and social obligations. It was $\mathrm{ACLEC}^{100}$ that noted:

... the need to maintain "the high professional and ethical standards upon which our legal system and, it could be said, our democracy depend". Pro bono services had been remarked upon in earlier reports, but here the linkage of standards with democratic values that include pro bono services, and the growing significance of law "between government and the governed at various levels" reveal a much more sophisticated regulatory concept of what standards might entail. ${ }^{101}$

The LETR, too, aims to ensure that LSET "advances the regulatory objectives of the Legal Services Act 2007 in the interests of society, consumers and justice" ${ }^{102}$ This public purpose of the legal profession could be fostered in universities in a number of ways, e.g. through encouraging student volunteering, ${ }^{103}$ Citizens Advice Bureau training, charity fundraising, peer-assisted learning schemes, or faculty student representation schemes. If academics actively support law students' engagement in activities that benefit the public, this is more than likely to instil in students the duty for public service, which is a trait of professionals according to the wider definition. ${ }^{104}$ Currently, in the legal profession there are many role models, often senior members of the profession, who show willingness to mentor future talent. Thus, it is possible that the public purpose of the legal profession could be instilled in students' behaviour, not only from within, but also from outside academia, too. In the words of David Edmonds, the Chair of the Legal Services Board:

If the law is ever more effectively to serve the public, then the profession - or rather the entire legal workforce - needs to have the right skills and knowledge. ... It is about achieving a constant interplay between practice and education, with the two spheres in constant dialogue, each driving improvement and innovation in the other to the broader public good. ${ }^{105}$

This leads to the professional institutional set-up, which greatly influences how students develop their professional identities. The ACLEC Report was the first to notice that there was a correlation with professionalism values embedded in the whole institution that practises these values, rather than just preaches them, especially in light of institutional self-assessment. ${ }^{106}$ Therefore, there is a need to concentrate not only on students' personal skills and values, but also on the professional values reflected and promoted in the educational environment and institutional culture. As Giroux observes, "the dominant culture is mediated in schools through textbooks, through the assumptions that teachers use to guide their work, through the meanings that students use to negotiate their classroom experiences, and through the form and content of school subjects themselves" ${ }^{107}$ What are the factors affecting the development of professionalism culture in the UK's law schools and departments today?

If we are to start developing the values and attitudes of professionalism at universities as part of the overall professional institutional set-up, it is essential not only that academics are trained as educationalists, but also that they lead students by example by consistently demonstrating what it means to be professional. The need for such role models is especially pertinent at HE institutions with an active widening participation (WP) agenda. Many WP students may not have had a professional role model in their lives; their tutors could be their first point of representation on what it means, and is, to be a professional. ${ }^{108}$ It is a positive sign that the LETR focuses on the promotion of fair access as one of the four issues critical to the future development of $\mathrm{LSET}^{109}$ and recommends "a range of institutional changes intended to support information flows and cultural change in the future regulation of LSET". ${ }^{110}$

The final problem that needs to be addressed in academia when ensuring that professionalism is embedded in different degrees is the current lack of high-quality pedagogy training for all academics. Even though it is recommended that educators should have competencies in academic knowledge, professional development and pedagogy training, ${ }^{111}$ the latter criterion is still overlooked in terms of the quality ${ }^{112}$ and inclusiveness ${ }^{113}$ of such 
training at many UK universities. In other words, even though there exists the HEA UK Professional Standards Framework, the plans to let students judge universities on how many of their academics hold teaching qualifications ${ }^{114}$ and a plethora of resources developed by the Higher Education Academy to support staff new to teaching, ${ }^{115}$ UK academia is not yet "professional in its teaching". ${ }^{116}$ Unfortunately, within the universities there still exists a wide distinction between professional academics (those who research) and professional educationalists, which contrasts with professional training of, for example, school teachers. ${ }^{117}$ Given that university students are changing - undergraduates are, arguably, less engaged by their courses and they are spending much less time studying than they did 40 years ago; ${ }^{118}$ open online courses (MOOCs) ${ }^{119}$ are becoming increasingly common; and technology is used to enhance knowledge delivery - there is a need to keep legal educators up to date with the new teaching and assessment methodologies of such students, at the same time engraining professionalism skills, values and attitudes into this framework. For the above reasons, "[a]cademics can ... no longer be researchers who teach. They must be general practitioners", ${ }^{120}$ or professionals-in-academia.

To summarise, this section has established how the three challenges set out above - linked to maintaining a common standard of professionalism in light of the changing landscape of legal services - could be overcome by educators. First, with regard to the public purpose of legal services, a clear message has been advanced: to maintain its social utility, future lawyers must be inculcated with the professional ethical values, attitudes and skills required to work effectively within not only the legal sector, but also other industries. Secondly, the institution that is providing the education must, in itself, embody professionalism. Academics must act and be seen to be professional in order to impart the values, attitudes and skills to their students. Thus, it is not enough to simply teach professionalism; academics must also practise it. This is inextricably linked with the final challenge, namely that pedagogy training for academics needs to become more professionalised in line with other professions.

\section{Conclusion}

The values and attitudes associated with being professional are developed and nurtured over time, very often through experience. Given the changing legal services landscape, with diverse pathways into working within the sector we, higher education professionals, should play a vital part. By ingraining professionalism within our degree programmes, we may be able to go some way to establishing a common standard of professionalism that can be developed within our students to ensure they are public service and employment-ready when they leave university, regardless of what industry they enter and, if they are employed within the legal sector, regardless of whether or not they are regulated.

This article has established that the changing landscape of legal services, emanating from the drive for consumerism and greater economic efficiency, amplifies the need for a consistent minimum standard of professionalism to be developed and applied within degree programmes. The LETR Report left "for each of the frontline regulators to decide, in the light of their regulatory responsibilities, what action they will take in response to the report's recommendations". ${ }^{121}$ Arguably, academia seems to be left out from this picture, even though the legal profession already regulates aspects of legal training such as knowledge (on the basis of the Qualifying Law Degree) and skills. To narrow this gap, it is important that both professional regulatory bodies and also educators work together to create a seamless process of legal education and training which retains professionalism, and especially the values of the legal profession, at its core. After all, if "professions involve (at least) a commitment to serve the interests of clients and the welfare of society", ${ }^{122}$ it is up to the whole sector to practise with the public interest at heart, and lead by a professional example. If a law degree is to be considered a "safe investment" by potential students who may pursue a variety of professional careers - such as foreign diplomats, civil servants, policy-makers, magistrates or scholars - it is essential that such an undergraduate degree includes training of professional skills, values and attitudes.

\section{Acknowledgements}

We are grateful to Lars Mosesson, Nigel Duncan, Hayley Coe and the two anonymous peer-reviewers for their very helpful comments on earlier drafts of this paper. 


\section{Notes}

1 This is especially evident in the Clementi Report that resulted in the Legal Services Act 2007; D. Clementi, Report of the Review of the Regulatory Framework for Legal Services in England and Wales (London, Department for Constitutional Affairs, 2004) (the Clementi Report), see chap. F generally. The LETR recognised the need to make legal services more accessible for consumers; see J. Webb, J. Ching, P. Maharg and A. Sherr, Setting Standards: The Future of Legal Services Education and Training Regulation in England and Wales (London: Legal Education and Training Review, 2013) (LETR Report). Available at: http://letr.org.uk/the-report/index.html. See also, Department for Constitutional Affairs, The Future of Legal Services: Putting Consumers First, White Paper Cm 6679 (Norwich, TSO, 2005) pp. 40-41. The paper sets out the benefits of the regime to consumers, including better access to justice, improved service and, of particular relevance to this article, for reasons set out below, convenience.

2 Legal Practice Course (LPC); Bar Professional Training Course (BPTC).

3 A training contract or a pupillage.

4 The Training Framework Review Group Reports (2005) and the Wood Reports; as cited in LETR Literature Review: Legal Education, Professional Standards and Regulation http://letr.org.uk/literature-review/index.html (accessed 15 January 2014), p. 2.

5 Ibid.

6 Ibid. The Literature Review (supra n. 4) provides a sound analytical summary of the Ormrod Committee and Lord Chancellor's Advisory Committee (ACLEC) reports, stressing the differences between the two.

7 "[European Union membership] and growth in international and comparative law courses; changes in legal practice leading to the creation of new subjects; the entry of universities and polytechnics to professional education; increased use of technology; increase in legal services and advice in law schools; diversification and intensification of legal research carried out by staff; European links and integration; ... the emerging profile of access and diversity issues, a range of new teaching methods and further specialization in legal topics; the increased profile of private legal education providers". Literature Review, supra n. 4, p. 12.

8 Ibid., p. 14.

9 LETR Report, supra n. 1, p. ix.

10 See n. 48 in N. Hamilton, "Assessing Professionalism: Measuring Progress in the Formation of an Ethical Professional Identity" (2008) 5 University of St Thomas Law Journal 470.

$11 \mathrm{lbid}$., p. 480.

12 Ibid. p. 481.

13 Ibid. p. 482.

14 LETR Report, supra n. 1, p. 118, p. 151.

15 lbid., pp. 127-128.

16 Ibid., p. 129.

17 Ibid., p. 139.

18 Ibid., p. 274.

19 Ibid., p. 118.

20 Meta-competencies are "higher level" abilities that enhance other competencies, or pull competence together; see G. Cheetham and G. Chivers, "Towards a Holistic Model of Professional Competence" (1996) 20(5) Journal of European Industrial Training 20 , p. 24.

21 R. Epstein and E. Hundert, "Defining and Assessing Professional Competence" (2002) 287 Journal of the American Medical Association 226 , p. 227.

$22 \mathrm{~J}$. Winterton, F. Delamare-Le Deist and E. Stringfellow, "Typology of Knowledge, Skills and Competences: Clarification of the Concept and Prototype" (2005), http://www. uk.ecorys.com/europeaninventory/publications/method/cedefop_typology.pdf (accessed 13 October 2013) p. 16.

23 H. Gardner, Frames of Mind: The Theory of Multiple Intelligences (3rd ed., New York, Basic Books, 2011); R.M. Harden, J.R. Crosby, M.H. Davis and M. Friedman, "AMEE Guide No. 14: Outcome-Based Education: Part 5 - From Competency to Meta-Competency: A Model for the Specification of Learning Outcomes" (1999) 21 Medical Teacher 546, p. 546.

24 A. Colby and W.M. Sullivan, "Formation of Professionalism and Purpose: Perspectives from the Preparation for the Professions Program" (2008) 5 University of St Thomas Law Journal 404, p. 405.

25 Ibid., p. 409.

26 LETR Report, supra n. 1, p. 121.

27 For an accepted employability skills model, see CareerEDGE Model of Graduate Employability developed by Dacre-Pool and Sewell: L. Dacre-Pool and P. Sewell, "The Key to Employability: Developing a Practical Model of Graduate Employability" (2007) 49 Education and Training 277.

28 E. Martin and G. Hess, "Developing a Skills and Professionalism Curriculum - Process and Product" (2010) 41 University of Toledo Law Review 327, pp. 329-330; Colby and Sullivan, supra n. 24. 
29 See e.g. D. Glover, S. Law and A. Youngman, “Graduateness and Employability: Student Perceptions of the Personal Outcomes of University Education" (2002) 7 Research in Post-Compulsory Education 293; P.J. Hager and S. Holland (eds), Graduate Attributes, Learning and Employability (Dordrecht, Springer, 2007).

30 A. Walsh and B. Kotzee, “Reconciling 'Graduateness' and Work-Based Learning” (2010) 4 Learning and Teaching in Higher Education 36, p. 37.

31 J.M. Steur, E.P.W.A. Jansen and W.H.A. Hofman, "Graduateness: An Empirical Examination of the Formative Function of University Education" (2012) 64 Higher Education 861.

32 Walsh and Kotzee, supra n. 30, p. 38.

33 LETR Report, supra n. 1, p. 122.

34 Colby and Sullivan, supra n. 24.

35 Clementi, supra n. 1.

36 Ibid. Chapter F, para. 6.

37 Both implemented by Part 5 Legal Services Act 2007.

38 Within an LDP, non-lawyers, such as accountants, can operate as managers to enhance the operational management of the practice, but cannot offer their specific professional services to the public. Clementi, supra n. 1, p. 7.

39 Ibid., p. 8.

40 In 2011 it was estimated some 5000 organisations would potentially enter the legal market: K. Underwood, "Alternative Business Structures Mean Consumers Will Lose Out" The Guardian (26 January 2011), http://www.theguardian.com/law/2011/jan/26/alternative-businessstructures-consumers-lose (accessed 7 October 2013).

41 The Co-operative, Legal Services (2013), http://www.co-operative.coop/legalservices (accessed 7 October 2013).

42 The Law Society, “Alternative Business Structures” (22 July 2013), http://www.lawsociety.org.uk/advice/practice-notes/alternativebusiness-structures/ (accessed 4 October 2013). According to this guidance, the licence may impose conditions to protect clients or the public interest that: (1) limits the activities of the ABS; (2) prevents the ABS from entering into particular business agreements or adopting practices; (3) makes the ABS take action to ensure that it provides legal services in a suitable manner.

43 SRA, "Register of Licensed Bodies (ABS)" (2013), http://www.sra.org.uk/absregister (accessed 7 October 2013). Pursuant to s.87(4) rules, the Legal Services Board requires the SRA to maintain and publish a register of ABS licensed bodies: Legal Services Board, "Registers of Licensed Bodies: Section 87(4) Rules" (2013),

http://www.legalservicesboard.org.uk/what_we_do/regulation/pdf/registers_of_licensed_bodies_rules.pdf (accessed 7 October 2013).

44 AA, “Legal Services: Key Benefits” (2013), http://www.theaa.com/legal-services/legal-documents.html (accessed 7 October 2013).

45 “Direct Line to Launch Legal Services Venture in Partnership with Parabis” Legal Week (2013), http://www.legalweek.com/legalweek/news/2282357/direct-line-to-launch-legal-services-venture-in-partnership-with-parabis (accessed 7 October 2013). Indeed, Hong Kong is in the process of following the United Kingdom's lead and introducing ABSs: E. Broomhall, “Firms in HK Could Get ABS Green Light as Law Society Mulls UK-Style Reforms" Legal Week (2013) 15 (31) p. 5.

46 LETR Report, supra n. 1, chap. 3, "Trends and Developments in the Legal Services Market", pp. 77-114.

$47 \mathrm{CBI}$ and Pearson, "Learning to Grow: What Employers Need from Education and Skills. Education and Skills Survey" (2012) p. 10.

48 It proposes to build the police profession by creating the College of Policing that has a "vital leadership role to play in developing the police into an evidence-based profession"; see Independent Police Commission, "Policing for a Better Britain" (2013) p. 7.

49 LETR Report, supra n. 1, p. 120.

50 Epstein and Hundert, supra n. 21.

51 LETR Report, supra n. 1, p. 123.

52 Prospects citing data from the Higher Education Statistics Agency; Prospects, "What Do Law Gradates Do?", http://www.prospects.ac.uk/options_law.htm (accessed 21 November 2013).

53 The figures are now at their lowest since training contract details were first recorded in 1998-1999, when 4827 were registered: Law Society, "Annual Statistical Report 2012" (2012).

54 M. Hardee, “Career Expectations of Students on Qualifying Law Degrees in England and Wales" (2012) pp. 43-44.

55 According to Bradney, a pure liberal law degree does not reflect the current demand for employability and consumerism: A. Bradney, Conversations, Choices and Chances: The Liberal Law School in the Twenty-First Century (Oxford, Hart, 2003) pp. 37-39. See also A. Boon, "Legal Ethics at the Initial Stage: A Model Curriculum" (The Law Society, 2010) p. 10.

56 B. Hepple, "The Renewal of the Liberal Law Degree" (1996) 55 Cambridge Law Journal 470, pp. 470-471.

57 H. Arthurs, “The Ormrod Report: A Canadian Reaction” (1971) 34 Modern Law Review 642, pp. 647-648.

58 Hepple, supra n. 56, p. 471.

59 lbid. 
60 Note that the LETR Report does not recommend a strong "vocationalisation" of law studies.

61 Literature Review, supra n. 4, p. 8.

62 See Recommendation 6.

63 LETR Report, supra n. 1, p. ix.

64 Ibid., p. xiv.

65 W.S. Albrecht and R.J. Sack, Accounting Education: Charting the Course Through a Perilous Future (Sarasota, FL, American Accounting Association, 2000); T. Forristal, "The Future of Accounting Education: The Response of Chartered Accountants" (2002) 1(1) Canadian Accounting Perspectives 53; T. Hassall, J. Joyce, J.L.A. Montano and J.A.D. Anes, "Priorities for the Development of Vocational Skills in Management Accountants: A European Perspective" (2005) 29 Accounting Forum 379.

66 G. Siegel and J. Sorenson, Counting More, Counting Less. The 1999 Practice Analysis of Management Accounting (Montvale, NJ, IMA, 1999); IMA and AICPA, "CPA Vision Project: Final Report" (2012), http://www.aicpa.org/RESEARCH/CPAHORIZONS2025/CPAVISIONPROJECT/Pages/CPAVisionProject.aspx (accessed 16 October 2013).

67 AICPA, Core Competency Framework for Entry into the Accounting Profession (New York, AICPA, 1999).

68 LETR Report, supra n. 1, p. xi; Recommendation 11.

69 Ibid., Recommendation 11.

70 As far as the subject-specific knowledge is concerned, the LETR recommends maintaining the current balance between Foundations of Legal Knowledge in the Qualifying Law Degree and Graduate Diploma in Law: "The revised requirements should, as at present, not exceed 180 credits within a standard three-year Qualifying Law Degree course", ibid., p. xv; Recommendation 10.

71 Ibid., Recommendation 11.

72 Ibid., p. xvi; see Recommendations 14-15: for example, supervisor training, the duration of supervised practice, the environments within which training is permitted, constraints on the nature of the person supervising.

73 See Recommendation 6.

74 Justice, Lawyers and the Legal System. A Critique of Legal Services in England and Wales (London, Justice Educational and Research Trust, 1977) p. 104.

75 Literature Review, supra n. 4, p. 7.

76 Ibid., p. 15.

77 LETR Report, supra n. 1, p. xiii.

78 Ibid.

79 PEAT 1: the Diploma in Professional Legal Practice.

80 LETR Report, supra n. 1, p. 127.

81 Ibid., p. xiv; Recommendation 7.

82 Ibid.

83 Ibid.

84 Literature Review, supra n. 4, p. 17.

85 HEFCE, “2013 Teaching Quality Information Data” (2013)

http://www.hefce.ac.uk/whatwedo/It/publicinfo/nationalstudentsurvey/nationalstudentsurveydata/2013/ (accessed 9 October 2013).

86 HEA, "Transforming Assessment in Higher Education Pilot Scheme" (March 2013),

http://www.heacademy.ac.uk/resources/detail/assessment/Transforming_assessment_pilot_CP/Transforming_assessment (accessed 9 October 2013).

87 LETR Report, supra n. 1, p. ix; see Recommendation 1.

88 Ibid.; see Recommendation 1.

89 Ibid., p. xiii; see Recommendation 2.

90 Ibid.; see Recommendation 3.

91 Ibid.; see Recommendation 5.

92 D. Lopez, J.-L. Cruz, F. Sanchez and A. Fernandez, "A Take-Home Exam to Assess Professional Skills", in Proceedings of the 2011 Frontiers in Education Conference (Washington, DC, IEEE Computer Society, 2011).

93 E.g. law problem scenarios.

94 E.g. mooting.

95 S. Prince and E. Dunne, “Group Development: The Integration of Skills into Law” (1998) 32(1) The Law Teacher 64. 
96 E.g. a session in the Supreme Court.

97 K. Hinett, C. Maughan, B. Lee and K. Stanton, "Managing Change in Assessment and Learning in Legal Education: A Tale of Two Cities" (1999) 33 The Law Teacher 135.

98 M.J. Davis, “Outcome-Based Education” (2003) 30 Journal of Veterinary Medical Education 227; H.A. Scicluna, M.C. Grimm, A.J. O’Sullivan, P. Harris, L.S. Pilotto, P.D. Jones and H.P. McNeil, "Clinical Capabilities of Graduates of an Outcomes-Based Integrated Medical Program" (2012) 12 BMC Medical Education, available online: http://www.biomedcentral.com/1472-6920/12/23.

99 The Future of Legal Services Education and Training Regulation in England and Wales, supra n. 9, p. x.

100 See Chapter 1 entitled "The Changing Needs of Legal Practice in the 21st Century"; ACLEC, "First Report on Legal Education and Training" (1996), http://www.ukcle.ac.uk/resources/he-policy/aclec/ (accessed 13 October 2013).

101 Literature Review, supra n. 4, p. 15.

102 LETR Review, supra n. 1, p. ix.

103 At Buckinghamshire New University this is organised through the Students Union.

104 Hamilton uses Robert Kegan's theory of social maturity (adulthood) when discussing the psychology of the formation of professional identity. According to Hamilton, the last two stages of adulthood take into account a reflective self-authored personal authority and deep understanding of public service. See N.W. Hamilton and V. Monson, "Legal Education's Ethical Challenge: Empirical Research on How Most Effectively to Foster Each Student's Professional Formation (Professionalism)” (2011) 9 University of St Thomas Law Journal 324, pp. 337-339.

105 D. Edmonds, “Training the Lawyers of the Future - a Regulator's View” (2011) 45 The Law Teacher 4, p. 6.

106 Literature Review, supra n. 4, pp. 15-16.

107 H.A. Giroux, Ideology, Culture and the Process of Schooling (Philadelphia, PA, Temple University Press, 1981) pp. 92-93.

108 Colby and Sullivan pose this question by way of a search for what constitutes a professional image (e.g. a lawyer as a zealous advocate versus keeper of the democracy); Colby and Sullivan, supra n. 24, pp. 417-419.

109 LETR Report, supra n. 1, Chapter 6.

110 Ibid., p. xi.

111 M.J. Bebeau, “Promoting Ethical Development and Professionalism: Insights from Educational Research in the Professions" (2008) 5 University of St Thomas Law Journal 366, p. 391. See also HEA, “The UK Professional Standards Framework" (2011), http://www.heacademy.ac.uk/ukpsf (accessed 16 October 2013).

112 The issue identified by the authors relates to the quality of the learning and teaching training available for academics, as opposed to the fact that it is increasingly becoming a contractual obligation. Undoubtedly, this is a wider issue that requires further exploration and analysis beyond the scope of this article.

113 Arguably, pedagogy training programmes should not alienate someone who comes to academia from working environment without having acquired a PhD; see L. Gourlay, “I'd Landed on the Moon': A New Lecturer Leaves the Academy” (2011) 16 Teaching in Higher Education 593.

114 J. Grove, "State Puts Weight behind Teaching Qualification Data" (29 August 2013), http://www.timeshighereducation.co.uk/news/stateputs-weight-behind-teaching-qualification-data/2006853.article (accessed 22 November 2013).

115 HEA, “New to Teaching”, http://www.heacademy.ac.uk/new-to-teaching (accessed 22 November 2013).

116 Literature Review, supra n. 4, p. 3.

$117 \mathrm{lbid}$

118 G.D. Kuh, "How Are We Doing? Tracking the Quality of the Undergraduate Experience, 1960s to the Present" (1999) 22 Review of Higher Education 99.

119 J. Baggaley, “MOOC Rampant” (2013) 34 Distance Education 368.

120 J. Radford, "Why I ... Think Higher Education Lecturers Need a Professional Training" Times Higher Education (4 December 2001), http://www.timeshighereducation.co.uk/news/why-i-think-higher-education-lecturers-need-a-professional-training/166307.article (accessed 22 November 2013).

121 LETR Report, supra n. 1, 9, p. x.

122 Colby and Sullivan, supra n. 24, p. 5. 